\begin{tabular}{lcr}
\hline \multicolumn{3}{c}{ A N N A L ES } \\
UNIVERSITATIS M A R I A E C URIE-SKŁ ODOWS K A \\
LOL. XXXVI & SECTIOFF & $1-2018$ \\
\hline
\end{tabular}

ALMIRA TATKENOVA

ORCID ID: https://orcid.org/0000-0002-0683-6533

Kazanskij Privolžskij Federalnyj Universitet

\title{
Address Forms and Gender in Political Discourse (The Case of Greek, Kazakh, and Russian)
}

Formy adresatywne i gender $\mathrm{w}$ dyskursie politycznym (na przykładzie języka greckiego, kazachskiego i rosyjskiego)

\section{INTRODUCTION}

Address forms, like any category of language that represents the gender dichotomization of human society, are involved in the construction of the social gender of discourse agents. Social implications of gender representation can be built on stereotypical models of behaviour, thinking, duties and roles ascribed to men and women. Prevalent gender ideologies come into play in the particular use of linguistic items. Address forms, defined as "a speaker's linguistic reference to his/her collocutors" (Braun, 1988: 7), also contribute to overtly and covertly gendered discourse.

Address forms comprise personal names, occupational and kin terms, titles, expressions that refer to one's gender, age, position, the so-called emotive forms and other groups. Among the factors that determine the use of address forms in Greek, Kazakh, and Russian, the researchers (Aysakova, 2008; Makri-Tsilipakou, 1983; Shadkam, 2004) single out formality of the situation, a person's social class, status, rank, age, sex, occupation, position, political affiliations, education, place of residence, kin relations, distance between speakers, and tone of communication, i.e. the extent to which communicators follow etiquette rules.

In Kazakh and Greek, the class of address forms includes honorific first names and honorific titles. In Kazakh, the first name can express (Mamaeva, 2003, : 22-23) 
high deference to an addressee when the affixes -(а)қа, -аға, -аха, -(ә)ке, -еке are attached: Жәке from Жамбыл, Ереке from Ерасыл, Сәке from Сарыбай. As a rule, honorific forms of address are exchanged between male communicators. In Greek (Makri-Tsilipakou, 1983), honorific address forms are based on titles:

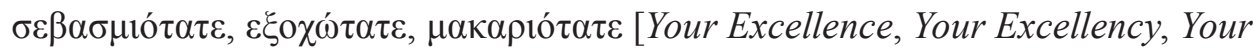
Holiness - added by A.T.].

The research on the use of address forms in political discourse in Polish (Jaworski and Galasiński, 2000) and Chinese (Kuo, 2003) acknowledge their complicated functions: in political debates the strategic choice of address forms helps participants gain political and interactional advantage over opponents, maintain a positive public image and gain legitimacy for their ideologies. Address forms tend to occur when a debater challenges his rivals.

But the aspect of gender in relation to address forms is rarely touched upon since the prevailing majority of the political elite are of male gender and in the discourse analyzed the main participants are men. An illustrative example (Aysakova, 2008: 25) is the slip of the tongue made by a TV-host when he addresses a woman-politician with господин/Mr. instead of госпожа/Ms.

\section{ADDRESS FORMS IN GREEK, KAZAKH, AND RUSSIAN POLITICAL DISCOURSE}

This paper is part of a broader study focused on the use of linguistic gender that embraces lexical gender, grammatical gender, and address forms as a subcategory based on both. The languages involved are Greek, Kazakh, and Russian: in contrast to Greek and Russian, grammatical gender is not a category available in the Kazakh language, where address forms resort to resources of lexical gender only. The objective of the contrastive analysis was to reveal possible commonalities and differences in the deployment of address forms in political interviews by searching for answers to a number of questions: when and why address forms are used by the speakers, what peculiarities of the interview as a genre contribute to their use, how they interact with the parameter of gender (as well as those of culture, setting, etc.), and what are the social implications of this interaction for participants in the three contexts. Asymmetries in power between an interviewer (henceforth: IR) and interviewee (henceforth: IE) are interpreted from the standpoint of Norman Fairclough's $(1989,1995)$ Critical Discourse Analysis, whose primary concern is to detect the exercise of power achieved via common sense ideological assumptions hidden behind routinely used conventions in discourse and in the consequent relations of domination and subordination. 
The data for the research are selected from the newspapers $T o B \dot{\eta} \mu \alpha \tau \eta \varsigma$ Кәрıкки́ৎ from Greece, Егемен Қазақсттан from Kazakhstan, and Известия from Russia. The three newspapers belong to quality press and have nationwide coverage. Due to the fact that all the politicians interviewed by the Russian newspaper are men, 19 interviews with female politicians in Russia have been selected from other sources. Thus, the total amount of data is 109 interviews.

The interplay of address forms and social category of gender in each of the three contexts is analyzed qualitatively and quantitatively. The qualitative analysis aims to reveal social motivations for particular uses of address forms in political interviews. The quantitative analysis provides the mean frequency of address forms: for instance, if the total number of address forms in the IE $\rightarrow$ IR axis in $10(33 \%)$ interviews is 25 , then $x=25: 10=2.5$. The mean frequency of address forms per 30 interviews $(100 \%)$ comes out from $x=25: 30=0.8$. Table 1 below displays the number of interviews and the frequency of address forms for each of the referents: IR, IE, and the third party discussed by the main participants.

Table 1. Address forms in Greek, Kazakh, and Russian interviews

\begin{tabular}{|l|c|c|c|c|c|c|}
\hline \multirow{2}{*}{ Referent } & \multicolumn{2}{c|}{ IR } & \multicolumn{2}{c|}{ IE } & \multicolumn{2}{c|}{$3^{\text {rd }}$ person } \\
\cline { 2 - 7 } Address forms & Number & Frequency & Number & Frequency & Number & Frequency \\
\hline \multirow{2}{*}{ Greek interviews } & $33 \%$ & 2.5 & $50 \%$ & 1.5 & - & - \\
& $100 \%$ & 0.8 & $100 \%$ & 0.7 & & \\
\hline \multirow{2}{*}{ Kazakh interviews } & - & - & $73 \%$ & 1.4 & - & - \\
\hline \multirow{2}{*}{ Russian interviews } & - & - & $33 \%$ & 1.2 & $3 \%$ & 1 \\
& & & $100 \%$ & 0.4 & $100 \%$ & 0.03 \\
\hline Russian interviews with & - & - & $68 \%$ & 2.4 & $5 \%$ & 1 \\
female politicians & & & $100 \%$ & 1.6 & $100 \%$ & 0.05 \\
\hline
\end{tabular}

Source: author's own elaboration

\section{ADDRESS FORMS IN GREEK INTERVIEWS}

The Greek data include 19 same-gender and 11 cross-gender interviews. The prevailing majority of politicians come from Né $\alpha \Delta \eta \mu$ $\Delta \rho \alpha \tau i$ (18 IEs) which was the ruling party during the period covered by the newspapers sampled. In the second place comes the other largest party in Greece - $\Pi \alpha \Sigma$ oK (8 IEs), while representatives of other parties (4 IEs) appear on newspaper pages quite infrequently.

As evident from Table 1, the distinguishing feature of the Greek interviews is address forms used by politicians, a phenomenon not observed at all in the Kazakh 
and Russian interviews. As a rule, the address form is expressed through the pat-

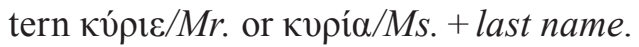

In $20 \%$ of the interviews, it is only the IR who is addressed. The imbalance between the number of address forms used by the male and female politicians is striking: 2, at most, by the former and 5 and 3 by the latter. Such a difference, when only the female IEs use address forms as cooperative markers including "the IR in a display of mutual understanding and cooperation in the beliefs of the speaker" (Winter, 1993: 124), is explained by the adversarial interviewing style of the male IR that can be characterized as an implicit form of gender construction.

The format of the interview as a genre presupposes, in its ideal form, the exchange of questions and replies on the part of the IR and the IE. Deviations from the norm, when instead of questioning, an IR resorts to assertions to express his/ her disagreement with an IE, critique of the policy pursued by the administration he/she represents, or objections, have been characterized (Clayman and Heritage, 2002; Inigo-Mora, 2008) as strategies of adversarialness.

In the Greek context, journalists break with the traditional form of conducting an interview in $60 \%$ of the interviews. This figure, nevertheless, does not speak of anything by itself since assertive statements perform different functions: they may set a new subject for discussion; they are used when the journalist is not satisfied with a politician's reply; and finally, they can render the evaluation of an IR. As a rule, this evaluation is a negative and critical one, with the critique concerning the efficiency of the government that the IE represents:

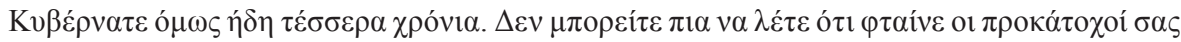

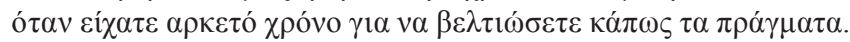

[But you have been in power for four years already. You can't say any longer that it is your predecessors who are to blame when you have had enough time to improve the situation.]

In the example, the IR immediately deprives the IE of the chance to accuse the party which had previously been in power of the existent state of things in the country. The presupposition is that the things have not been changed for the better by the ruling party whom the IE represents, though the party has been governing for four years, defined by the IR as a period of time long enough to improve the situation.

The style of the IR can be rather imposing: the use of the modal verb in the example below is prescriptive to the IE and it is presupposed that there is something to be criticised about the policy of the then government of which the IE is a member. The IR openly points to the contradiction between what the IE says and does, thus forcing her to speak about the flaws of her administration: 


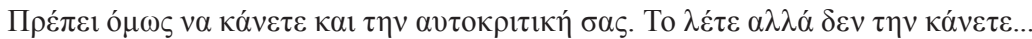

[You must give some self-criticism as well. You say that but you never do it...]

Statements of this kind, i.e. with a critical assessment, prevail in the interviews with female politicians, and the examples above come from the interviews with two female ministers. The women who have already reached a position of significant power (the IEs in question are Minister of Foreign Affairs and Minister of Labour and Social Protection) tend to undergo greater scrutiny and critical interrogation, in contrast both to their female colleagues from the opposition camp and their male counterparts. The more important the position of a female politician and the more sensitive the political issues related to this position, the more extended and tense is the interview and the more adversarial the interviewing style adopted by the mass media representative.

The use of address forms can be reciprocal as it is in some above-mentioned cross-gender talks where the IR is the male editor-in-chief of the newspaper and the IE is the female minister. The address from the IR to the IE exploits predominantly

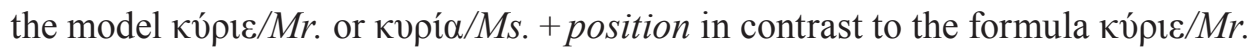
or кupía/Ms. + last name. The IR uses the address form traditionally at the very beginning of the talk and, for the second time, in a statement that rejects what has been said by the IE:

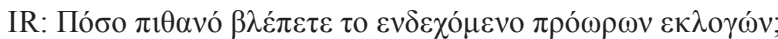

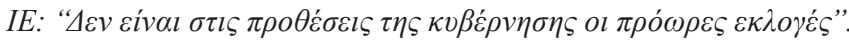

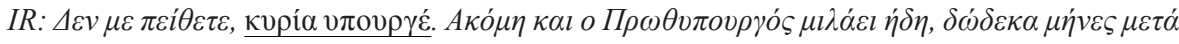

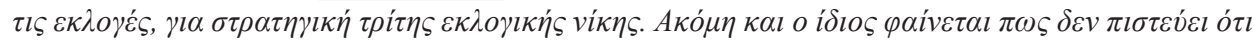

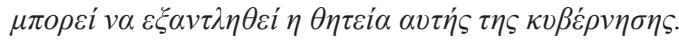

[IR: How possible, in your opinion, are pre-term elections?

IE: Pre-term elections are not being considered by the government.

IR: You fail to convince me, Ms. Minister. The Prime-Minister himself is already talking, 12 months after the elections, about the strategy for winning the third election. He himself does not seem to believe that this government will stay in power till the end of its term.]

The address form here mitigates the adversarial and threatening tone of the utterance produced out of disagreement - the strategy called "giving deference" when "deference serves to defuse potential face-threatening acts by indicating that the addressee's rights to relative immunity from imposition are recognized" (Brown and Levinson, 1987: 178). The IR openly and uncompromisingly undermines the opinion of the IE: her social role in the interview is that of a politician and this implies in this particular case that as such she is to be aware of the most likely developments to events when the Prime-Minister himself does not deny the 
possibility of elections. The straightforward assertion and reference to the PrimeMinister deprives the IE of a chance to give grounds for her opinion.

\section{ADDRESS FORMS IN KAZAKH INTERVIEWS}

In the Kazakh context, out of 30 talks, 23 are same-gender interviews, 6 are cross-gender talks, and in a single case the IR is not identified. Nearly all the politicians (29 IEs) come from the ruling party Нұр Отан.

In the Kazakh interviews, there is no address found in the direction from IE to IR. The number of talks where the politician is addressed by the journalist is the highest in the data. The forms used to address the IE are as follows:

1. The model first name + patronymic (the latter is formed with the help of the lexemes ұлы/son and қызы/daughter): Тобылбек Есенжолұлы - Tobylbek Esenjoluly;

2. Honorific forms:

Құрметті Әбеке, жылдың басты құжаты саналатын Елбасы Жолдауының жария етілуі қ̧ай кезде де орасан мәнді оқиға.

[Dear Abeke, the publication of the President's Message, which is considered to be the main document of the year, is always a very significant event.]

The special deference expressed by the honorific name is intensified by the adjective preceding it. It should be mentioned that honorific forms in the speakeraddressee axis are used quite exclusively and are traditionally used by male IRs to address male IEs. Moreover, they are applied only to address IEs who have made a considerable contribution to art and science: in the example above, the politician interviewed is the prominent Kazakh writer Abish Kekilbayev.

\section{ADDRESS FORMS IN RUSSIAN INTERVIEWS}

In the Russian data, 14 interviews are cross-gender talks, 13 are same-gender talks, and in 3 interviews the IR is not identified. The IEs in all the 30 cases are men and most of them belong to the ruling party Единая Россия (28 IEs). The phenomenon of such a homogeneous representation of political forces as regards gender can be accounted for by the fact that most of the discussions predominantly rotate around issues of the external policy of the state: in $70 \%$ of the texts, the politicians interviewed are representatives of Russia to NATO, the Foreign Minister 
or Foreign Deputy Minister, ambassadors, or politicians chairing economic and political organizations. And though there are women of high rank in Russian politics, most of those responsible for external affairs are men.

The address form used in the interviews follows the deferential model first name + patronymic: Николай Платонович [Nikolay Platonovich]. The use of address forms is not reciprocal since it is always the IE who is addressed.

Only once is the IE addressed by his first name: Алексей - Alexey due to his young age and rather informal style of the interview. The IE who is an activist of the youth movement Россия молодая (literally "Russia the Young") depicts his experience of being a "member" of the "National-Bolshevist Party" for over a year in order to find out what the "enemy" looks like from inside. At the end of the interview, the IE uses the chance to address the third party from the newspaper pages:

IR: Что вы хотели бы сказать своим недавним «однопартийцам»?

IE: Ребята, большинство из вас-нормальные люди. Не нравится вам власть-идите в оппозииию, протестуйте. На то у нас демократия, слава богу. Но посмотрите же сначала, за кого бороться!

[IR: What would you like to say to your recent "party colleagues"?

IE: Guys, most of you are sensible people. You don't like those in power-join the opposition, protest. We have democracy for that, thank God. But do check first who to fight for! ]

Earlier in the text, the IE explains that lots of the party members were imprisoned for extremist activities organized by the leader of the party. The motives that attract them to join the party are related to their gender and age, not to ideological stances or particular ideas. In this way, the speaker discredits the leader of the party for exploiting boys predominantly from challenging backgrounds who have many problems including "problems with the opposite sex", etc. His answers are heavily expressive of existing gender ideologies: every young man needs his own "pack"; every young man has the ambition to become somebody, to succeed. This "pack" is a male-dominated youth movement, participation in which gives them the feeling of solidarity, friendship, of a certain unity and a sense that the group will stand up for each of its members. The IE calls these guys to join the real opposition instead of being exploited: the address form in the extract includes only people of male gender since politics obviously remains "men's business".

In the 19 talks with women, the address form is the same deferential first name + patronymic and its use is not characterized by peculiarities concerning the IEs' gender. 


\section{CONCLUSION}

Participants of political interviews, as is evident from the findings described above, give preference to the most neutral and official way of addressing a person as prescribed by the formal and institutional setting of an interview. Deployed by speakers from mass media and politics, address forms fulfill a number of functions. In all the three contexts, they are used by IRs for conventional functions, i.e. to signal the start of a conversation or to change the subject.

However, in the Greek context, apart from that, there are cases when their use means more than referring to a person by his/her name or position: in other words, when address forms and gender intersect. It is most frequently female politicians - representatives of the ruling party - who deal with adversarial strategies of interviewing on the part of a male journalist. In some instances, IRs also apply address forms to mitigate aggressive assertive utterances; yet still, far more often women ministers use address forms as cooperative markers in order to turn a confrontational talk into a collaborative one. As the findings show, the Greek newspaper does not suggest affiliations with any of the political opponents it interviews and takes the function of "the public voice". For each political grouping and their representatives, it makes sense to have a journalist on his/her side, since a politician's image depends on how skillfully he/she controls his/her verbal behaviour in the course of the interview, replying to most "inconvenient" questions. However, the style of interviewing becomes extremely hostile when female politicians come into focus: questions are substituted for direct, uncompromising statements, which shape, in turn, the IEs' linguistic behaviour.

Politicians in the Kazakh and Russian media do not face gender-related aggressive interviewing, since the newspapers belong to the government and serve as a platform for senior officials, which explains why the interviews are of cooperation rather than contestation type. Nevertheless, the Kazakh data do provide evidence of when the use of address forms and gender are interconnected: Kazakh honorific names preserve the tendency to be exchanged by male speakers. It should be noted, however, that they emerge exclusively to address only those male politicians (writers, scientists) whose achievements are acknowledged nationwide and thus express the IR's sincere deference. Along with gender, respect for age is another important component of Kazakh culture and it accounts for a higher frequency of address forms received by Kazakh IEs in contrast to Greek and Russian counterparts, since most politicians achieve their status at an older age.

In the Russian context, the use of address forms in talk with male and female politicians is not found to be related to social gender. Still, it shows that politics and "serious" political issues (e.g. external affairs) are perceived in the society as 
matters to be tackled by men, which explains the homogeneous structure in high political office as well as in youth political movements.

Politics is a domain characterized by gender inequality in most of the societies: in one context, it is evident in the numerical under-representation, indeed the absence of women in interviews on serious, crucial issues, in the others - in the use of address forms informative of patriarchal gender expectations and ideologies.

\section{REFERENCES}

Aysakova, E.A. (2008). Sotsial'naya i sotsiokul'turnaya differentsiatsiya obrashcheniy v sovremennom russkom yazyke. PhD thesis. Moscow: MTSU.

Braun, F. (1988). Terms of Address: Problems of Patterns and Usage in Various Languages and Cultures. Berlin/NY/Amsterdam: Mouton de Gruyter.

Brown, P. \& Levinson, S. C. (1987). Politeness. Some Universals in Language Use. Cambridge: Cambridge University Press.

Clayman, S.E. \& Heritage, J. (2002). Questioning presidents: journalistic deference and adversarialness in the press conferences of U.S. Presidents Eisenhower \& Reagan. Journal of Communication, 52, 749-775. Https://doi.org/10.1111/j.1460-2466.2002.tb02572.x

Fairclough, N. (1989). Language and Power. London/NY: Longman.

Fairclough, N. (1995). Media Discourse. London: Arnold.

Inigo-Mora, I. (2008). Politicheskoe teleinterv'yu: neytralitet i provotsirovanie. Politicheskaya lingvistika, 1(24), 33-39.

Jaworski, A. \& Galasiński, D. (2000). Vocative address forms and ideological legitimization in political debates. Discourse Studies, 2(1), 35-53. Https://doi.org/10.1177/1461445600002001002

Kuo, S. (2003). The use of address forms in Chinese political discourse: analyzing the 1998 Taipei mayoral debates. The Tsing Hu Journal of Chinese Studies. New Series, 33(1), 153-172.

Makri-Tsilipakou, M. (1983). Apopira perigrafis tis neoellinikis prosfonisis. Meletes gia tin Elliniki Glossa, 5, 219-239.

Mamaeva, G.B. (2003). Erler men aielderdin soz koldanystaryndagy erekshelikter (genderlik zertteu). PhD thesis. Almaty: Al-Farabi KNU.

Shadkam, Z. (2004). Kazakh jane turik tilderindegi karatpa soz formasi, koldanylu erekshelikteri. Kazakh Tili men Adebieti, 8, 94-99.

Winter, J. (1993). Gender and the political interview in an Australian context. Journal of Pragmatics, 20, 117-139. Https://doi.org/10.1016/0378-2166(93)90079-5

\footnotetext{
ABSTRACT

The dominant ideologies of a society including those related to gender are put into practice via particular use of language. This paper presents findings from contrastive research that views address forms as a subcategory of linguistic gender involved in social gender construction in Kazakh, Russian, and Greek political discourse: it discusses commonalities and differences from the viewpoint of Critical Discourse Analysis, which detects the social character of linguistic preferences and their role in existent power relations in the society. As the results illustrate, along with the speakers' gender, there are other factors (the interviewee's status, political affiliations of the newspaper,
} 
cultural norms) that shape the choice of address forms, communicative strategies of the speakers and type of interview (cooperation or contestation). Unequal distribution of power in the societies is evident not only in women's numerical representation in socially and politically significant positions but also in covertly gendered political discourse, with mass media representatives resorting to adversarial strategies of interviewing, and female politicians seem to be held responsible for all the flaws of their political institutions and are obliged to defend their right to be in power.

Keywords: gender, address forms, political discourse, contrastive analysis

\begin{abstract}
ABSTRAKT
Ideologie dominujące w społeczeństwie, w tym związane z płcią, są wdrażane przez użycie określonych środków językowych. Artykuł przedstawia rezultaty badań kontrastywnych, które rozpatrują formy adresatywne jako podkategorię płci językowej biorącej udział w tworzeniu płci społecznej w kazachskim, rosyjskim i greckim dyskursie politycznym; omawia ich cechy wspólne i różnice z punktu widzenia krytycznej analizy dyskursu, ujawniającej społeczny charakter przyzwyczajeń językowych i ich rolę w istniejącym układzie sił w stosunkach społecznych. Jak pokazują wyniki badań, obok płci mówiącego istnieją inne czynniki (status rozmówcy, orientacja polityczna gazety, normy kulturowe) wpływające na wybór formy adresatywnej, strategii komunikacyjnej i typu rozmowy (współpraca lub konfrontacja). Nierówny podział władzy w społeczeństwach jest widoczny nie tylko w niskim odsetku kobiet zajmujących ważne stanowiska społeczne i polityczne, lecz również w skrytym genderowym dyskursie politycznym, w którym przedstawiciele mass mediów uciekają się do konfliktowych strategii prowadzenia rozmów, a kobiety-politycy wydają się być odpowiedzialne za wszystkie słabości swoich politycznych sojuszy i są zobowiązane do obrony swojego prawa do bycia u władzy.
\end{abstract}

Słowa kluczowe: gender, formy adresatywne, dyskurs polityczny, analiza kontrastywna 